\title{
Onchocerca - infected cattle produce strong antibody responses to excretory- secretory proteins released from adult male Onchocerca ochengi worms
}

Djafsia Boursou', Dieudonné Ndjonka ${ }^{1 *}$, Albert Eisenbarth ${ }^{2,3}$, Kingsley Manchang $^{4}$, Archille Paguem¹, Nancy Ngwafu Ngwasiri ${ }^{1}$, Jacqueline Dikti Vildina ${ }^{1}$, Babette Abanda ${ }^{1}$, Ralf Krumkamp ${ }^{5}$, Silke van Hoorn ${ }^{5}$, Alfons Renz ${ }^{3}$, Mbunkah Daniel Achukwi ${ }^{7}$ Eva Liebau ${ }^{6}$ and Norbert W. Brattig ${ }^{5}$

\begin{abstract}
Background: The front line molecules from filarial worms and other nematodes or helminthes are their ExcretorySecretory (ES) products. Their interaction with the host cells, proteins and immune system accounts for the skin and eye pathology or hyposensitivity observed in human onchocerciasis. ES products and adult worms' crude extracts from Onchocerca ochengi, a filarial nematode that infects the African zebu cattle, were utilized in the present study as a model for studying Onchocerca volvulus that causes river blindness in man.

Methods: The ES products were generated from adult male and female worms in vitro and analyzed with poly acrylamide gel electrophoresis (PAGE) and enzyme-linked immunosorbent assay (ELISA) using sera from Onchocercainfected cattle and humans. The cattle sera were collected from a herd that had been exposed for six years to natural transmission of Onchocerca spp. The expressed reactivity was evaluated and differences analyzed statistically using Kruskal-Wallis rank and Chi-square tests.

Results: The gel electrophoretic analyses of 156 ES products from O. ochengi female and male worms and of two somatic extracts from three females and 25 males revealed differences in the protein pattern showing pronounced bands at 15,30-50 and $75 \mathrm{kDa}$ for male ES proteins and 15, 25 and 40-75 kDa for somatic extracts, respectively and less than $100 \mathrm{kDa}$ for female worms. Proteins in the ES products and somatic extracts from female and male Onchocerca ochengi worms were recognized by IgG in sera from both Onchocerca-exposed cattle and humans. Bovine serum antibodies reacted more strongly with proteins in the somatic extracts than with those in the ES products. Interestingly, the reaction was higher with male ES products than with ES products from female worms, suggesting that the males which migrate from one nodule to another are more exposed to the host immune system than the females which remain encapsulated in intradermal nodules.
\end{abstract}

Conclusions: This study demonstrates that O. ochengi ES products and, in particular, extracts from male filariae may represent a good source of immunogenic proteins and potential vaccine candidates.

Keywords: O. ochengi, Excretory/secretory products, Onchocerciasis, lgG reactivity, Antigenicity

\footnotetext{
* Correspondence: ndjonka_dede@yahoo.com

'University of Ngaoundéré, Faculty of Science, Ngaoundéré, Cameroon

Full list of author information is available at the end of the article
}

(c) The Author(s). 2018 Open Access This article is distributed under the terms of the Creative Commons Attribution 4.0 International License (http://creativecommons.org/licenses/by/4.0/), which permits unrestricted use, distribution, and reproduction in any medium, provided you give appropriate credit to the original author(s) and the source, provide a link to the Creative Commons license, and indicate if changes were made. The Creative Commons Public Domain Dedication waiver (http://creativecommons.org/publicdomain/zero/1.0/) applies to the data made available in this article, unless otherwise stated. 


\section{Background}

Onchocerciasis, commonly known as river blindness, remains a health problem for countries in tropical Africa, Latin America and the Arabian Peninsula. This filarial disease is caused by Onchocerca volvulus and nowadays affects 15.5 million people worldwide [1]. O. volvulus adult females live in subcutaneous nodules for more than 10 years and produce up to 1500 microfilariae per day, which can live in the skin for up to several months (or even years) whilst waiting to be taken up during a blood meal of the vector fly $[2,3]$.

Onchocerca ochengi, a bovine parasite of Zebu cattle in Africa is the closest related species to O. volvulus and both parasites are transmitted by the same blackfly Simulium damnosum sensu lato which breeds in fast flowing rivers, making it an appropriate natural model for studying the biology [4], chemotherapy [5] and immunology of noduleforming Onchocerca parasites [6-8].

Like all helminths, nematodes are known to release products that enable them to invade, develop and persist inside a host by modulating the host immune response [9-11]. Intra and interspecific regulatory mechanisms of the worm-population are based on such putative ESproducts which may also be used by the sedentary female worms to attract male worms for reproduction. Such molecules can be collected in worm cultures as in-vitro excretory-secretory (ES) products [12]. Due to their close relationship, $O$. ochengi possesses a high number of proteins homologous to those of the human parasite $O$. volvulus as evidenced on SDS-gels [13, 14]. Their closeness with regards to the elicitation of immune mechanisms was also proven via the successful immunization of cattle against $O$. ochengi using live third-stage larvae (L3) of the human parasite O. volvulus [15].

O. ochengi ES products released into the nodule fluid and produced by male adult worms during reproduction have been reported to contain proteins which may be potential vaccine candidates $[16,17]$. The observed diversity noticed in this previous study was evaluated for the different developmental stages and gave an insight on the huge diversity of $O$. ochengi proteins. In addition, antigens in the somatic extract from adult female worms of $O$. ochengi were found to be as sensitive and specific as $O$. volvulus female antigens used for the diagnosis of human onchocerciasis [18].

During the course of a helminth infection, the hostparasite relationship must shift from the naïve, receptive stage, which allows the establishment of a number of worms, sufficient for reproduction and for maintaining endemicity, to a phase of 'premunition'. This phase regulates the size of the surviving adult worm population and leads to a phase of 'post-patency', where worm loads may decline, while the host usually remains open to re-infection [19].
The aim of our longitudinal follow-up of a cattle herd, exposed to natural infection is the study of such shifting host-parasite relationship over the lifespan of the parasite and its host, which is in the magnitude of many years, whilst an acute immune reaction to a particular 'antigen' takes only two weeks to manifest. The purpose of the present work was to evaluate and compare secreted or/and excreted (ES) and extracted (Somatic Extract) proteins from female and male adult worms of $O$. ochengi, and to examine the immune recognition of these proteins by antibodies from human hosts and cattle exposed to infection during the initial phase of infection of up to 36 months.

\section{Methods}

\section{Generation of ES products: culture of adult O. ochengi worms, harvesting and analysis of ES products by gel electrophoresis}

Skin samples from the inguinal area of mostly female slaughtered cattle containing palpable $O$. ochengi nodules were collected as described by Wahl et al. [4] from the slaughter house of Ngaoundéré (Cameroon). Samples were taken directly to the Programme Onchocercoses field laboratory of the University of Tübingen in Ngaoundéré within two hours. Skin samples were then washed thoroughly with distilled water, then with $70 \%$ ethanol, and left to dry for $10 \mathrm{~min}$. If not stated otherwise, all chemicals were purchased from Sigma-Aldrich (Deisenhofen, Germany).

Individual nodules were dissected and isolated from the skin using a scalpel blade, and put directly in phosphate buffered saline (PBS-pH 7.2). Females were isolated by digestion of the nodule with $5 \%$ collagenase for $10-15 \mathrm{~h}$ at $37{ }^{\circ} \mathrm{C}$ [20] and cleaned using sterile PBS supplemented with $100 \mathrm{U} / \mathrm{ml}$ penicillin and $100 \mu \mathrm{g} / \mathrm{ml}$ streptomycin. Male $O$. ochengi were collected by dissection of undigested nodules under a binocular microscope. Isolated males were washed three times in sterile PBS, and both, male and female worms were washed twice in the RPMI 1640 culture medium supplemented with penicillin $100 \mathrm{U} / \mathrm{ml}$, streptomycin $100 \mu \mathrm{g} / \mathrm{ml}$, Lglutamine and $0.08 \mathrm{mg} / \mathrm{ml} \mathrm{NaHCO}_{3}$, as described by Cho-Ngwa et al. [21] and modified by Ndjonka et al. [22]. The integrity of the cultured worms was carefully checked prior to incubation. Wounded worms were generally discarded. In vitro- culture was performed in 24well culture plates at $37{ }^{\circ} \mathrm{C}$ and $5 \% \mathrm{CO}_{2}$ with a maximum of 25 males or, depending on the worm size, with 1-3 females per well in $2 \mathrm{ml}$ of supplemented RPMI 1640 medium. Females were about 10 times longer than males. After every $48 \mathrm{~h}$, culture media were changed and stored at $-20{ }^{\circ} \mathrm{C}$ in $10 \%$ trichloroacetic acid (TCA) for subsequent analysis. The culture was continued until a maximal time of 8 days, beyond which the worms were 
usually not alive. Dead worms were removed when detected. From the ES products produced by the research group, 250 batches were investigated in the present study.

Stored culture media were thawed in the helminthology laboratory at the Bernhard Nocht Institute for Tropical Medicine in Hamburg (BNITM) and centrifuged in $2 \mathrm{ml}$ Eppendorf tubes at high speed $(5000 \mathrm{x} \mathrm{g}$ for $15 \mathrm{~min}$ ). This procedure was repeated up to six times to concentrate ES products from 3 to 6 females and up to 60 males. The supernatant was discarded, the pellet resuspended in $8 \mu \mathrm{l}$ RPMI 1640 medium into which were added $2 \mu \mathrm{l}$ of $10 \mathrm{x}$ concentrated loading buffer (Biorad, California, USA) and heated at $95{ }^{\circ} \mathrm{C}$ for $5 \mathrm{~min}$. Samples were then put on ice for $2 \mathrm{~min}$, spun down (quick spin), loaded onto $10 \%$ sodium dodecyl sulphate polyacrylamide gels and, after electrophoresis, stained with $0.1 \%$ Coomassie brilliant blue stain (Carl Roth, Karlsruhe, Germany). The destaining procedure was performed with acetic acid-methanol solution and the gel was washed using distilled water for a minimum of $4 \mathrm{~h}$ until complete destaining of the protein-free part of the gel. The stained gel was scanned using a Canon scanner (Canon CanoScan LIDE 220; Canon, Krefeld, Germany).

\section{Preparation of adult worm somatic extracts}

Male worms were isolated without collagenase-digestion, while female $O$. ochengi worms isolated and recovered from collagenase-digested nodules as described above, were frozen and sent to the BNITM. O. volvulus female worms from Ghanaian patients were provided by $\mathrm{N}$. Brattig from the BNITM [23, 24]. In Hamburg, worms were thawed at room temperature $\left(25^{\circ}-30{ }^{\circ} \mathrm{C}\right) .0 .5 \mathrm{~g}$ and $3 \mathrm{~g}$ of adult male and female worms respectively were mixed with a small volume of liquid nitrogen and ground using a mortar $[23,25,26]$. Three to six milliliters of PBS was added to the ground paste, the mixture was sonicated on ice in a $15 \mathrm{ml}$ Falcon tube and kept at $-70{ }^{\circ} \mathrm{C}$ for $24 \mathrm{~h}$. After defrosting, the mixture was sonicated once more on ice and centrifuged at 10,000 g for $10 \mathrm{~min}$. The supernatant was collected and the amount of protein evaluated using the Bradford quantification method. For the present study one batch, comprising filariae from five nodules from Ghanaian onchocerciasis patients, was applied and five batches of $O$. ochengi nodules from exposed cattle for the isolation of non-gravid female and male worms. Microfilariae were excluded. For the gel electrophoretic analysis one batch of $O$. ochengi female and male worms and females from $O$. volvulus extracts was applied. Concerning the serological analyses, ELISA tests were performed in parallel when transitioning between antigen batches and comparability between them was verified.

\section{Collection of sera}

Sera originated from Gudali (Bos indicus) cattle exposed since birth to $O$. ochengi transmission for 4 months $(n=28)$ or 36 months $(n=24)$ in a paddock situated along the banks of the river Vina du Sud. The dams which produced those calves are known to be infested with variable parasite burden of $O$. ochengi. The sampled calves showed variable nodule and microfilariae loads. The nodule burden ranked form 1 to 350/cattle (median: 47) and 11 microfilariae/mg of skin were counted at 36 month post-infection of the calves. Human sera originated from the Ghanaian onchocerciasis patients exhibiting microfilarial loads of up to 106 microfilariae/mg of skin.

\section{Enzyme linked immunosorbent assay (ELISA)}

A semi-quantitative analysis of serum IgG antibody levels was performed by ELISA to find antibody endpoints, as described previously by Mpagi et al. [27] with modifications adapted to the analysis of cattle sera. As positive controls to the ES proteins, O. volvulus and $O$. ochengi extracts were used in the ELISA assays. ES products from female and male $O$. ochengi as well as somatic extracts of $O$. ochengi and $O$. volvulus were used as antigens. The 96-microwell polystyrene plates (Nunc, Roskilde, Denmark) were coated with 200 ng of antigen in carbonate buffer ( $\mathrm{pH}$ 9.6) per well and incubated overnight at $4{ }^{\circ} \mathrm{C} .24 \mathrm{~h}$ later the plate was washed 4 times with $\mathrm{PBS}+0.05 \%$ Tween 20 . After removing unbound proteins, the plate was blocked with $200 \mu \mathrm{l}$ of $5 \%$ bovine serum albumin (BSA) per well for $2 \mathrm{~h}$ at $37^{\circ} \mathrm{C}$. Excess BSA was removed by washing 4 times with PBS $+0.05 \%$ Tween 20 , and the plate was incubated for another $2 \mathrm{~h}$ at $37{ }^{\circ} \mathrm{C}$ with dilutions between 500 and 10,000 in $200 \mu \mathrm{l}$ PBS $+0.5 \%$ BSA of either cattle sera or sera from the 36 patients with $O$. volvulus infection from an earlier study [27]. Sera from naïve, non-exposed cattle from the University of Veterinary Medicine (Hannover, Germany) and healthy Europeans were included as negative controls. The non-specifically bound antibodies were washed out with $\mathrm{PBS}+0.05 \%$ Tween 20 and the plate was incubated for one hour at $37^{\circ} \mathrm{C}$ with $100 \mu \mathrm{l}$ of $1 / 1000$ diluted horseradish peroxidase-conjugated goat anti-bovine IgG or goat anti-human IgG (Sigma, St. Louis, USA). The detection was performed using $100 \mu \mathrm{l}$ of tetramethylbenzidine (TMB) substrate in the dark for $5 \mathrm{~min}$ and stopping the reaction with $0.02 \% \mathrm{H}_{2} \mathrm{SO}_{4}$ at room temperature. The optical density (OD) was measured at $405 \mathrm{~nm}$ using an ELISA reader (Dynatech, Denkendorf, Germany).

\section{Data analysis}

The Kruskal-Wallis test was used for intra-group comparison, followed by Dunn's multiple test to compare the reactivity of immunoglobulins to ES and somatic extract 
proteins. Optical density (OD) values were transformed into index values $[28,29]$ using a linear regression analysis including a boundary for negative control sera $(+3$ $\mathrm{SD})$ at $\mathrm{OD}=0.150$. The distributions of the measured IgG indices for the cattle and human sera were described using the median and the interquartile range (IQR). Changes among repeated IgG measurements at two time points were compared using a Wilcoxon signed-rank test for paired data In case several samples showed no detectable IgG index, the data were dichotomised $(0=$ non-reactivity, $1=$ detectable activity $)$ and a Chi-square test was performed to assess differences in IgG expression. Data analysis was done using STATA 14 (College Station, TX: StataCorp LP). Statistical difference at $p<0.05$ was considered significant.

\section{Results}

\section{Harvesting and analysis of ES products}

Three hundred and ten worm cultures generated by adult females or males of $O$. ochengi were collected in $2 \mathrm{ml}$ of culture medium of which 250 ES products could be analysed. These ES cultures included gravid or nongravid females and cultures with up to 25 males.

All processed samples were analysed by SDS-PAGE to detect the pattern of the respective protein bands. Only
156 ES samples showed protein bands of various molecular masses.

For comparison of parasite sexes two gels were run separating extracts from non-gravid female or from male $O$. ochengi worms showing more frequent and dense proteins between 10 to $>200 \mathrm{kDa}$ for female extracts (Fig. 1a). Proteins in non-gravid female extracts displayed prominent bands at $12-15,18,23,27,37-40,50$, 70 and $\geq 100 \mathrm{kDa}$, while prominent protein bands in male extracts occurred at 15, 25, 30,37-50, 100 and $150 \mathrm{kDa}$. Major differences between proteins in the two sexes included dominant bands at $<15,23,40$ and high molecular mass $>200 \mathrm{kDa}$ for female worms, while males showed a more prominent band at $15 \mathrm{kDa}$. Thus, extracts of female worms comprised different proteins from those of male worms.

In spite of the remarkable variability of the ES samples' protein patterns, a higher proportion of ES proteins from females were of low molecular mass with protein bands between 30 and 50 and $\leq 100 \mathrm{kDa}$. Male ES proteins instead showed prominent band at 15-27 and 50$75 \mathrm{kDa}$ (Fig. 1b). At $48 \mathrm{~h}$, the 4 females' ES products showed more prominent protein bands as compared to the other 23 males' ES products protein patterns. For female ES products after $24 \mathrm{~h}$, two lanes (one for products from 2 females and the other one for those from 3

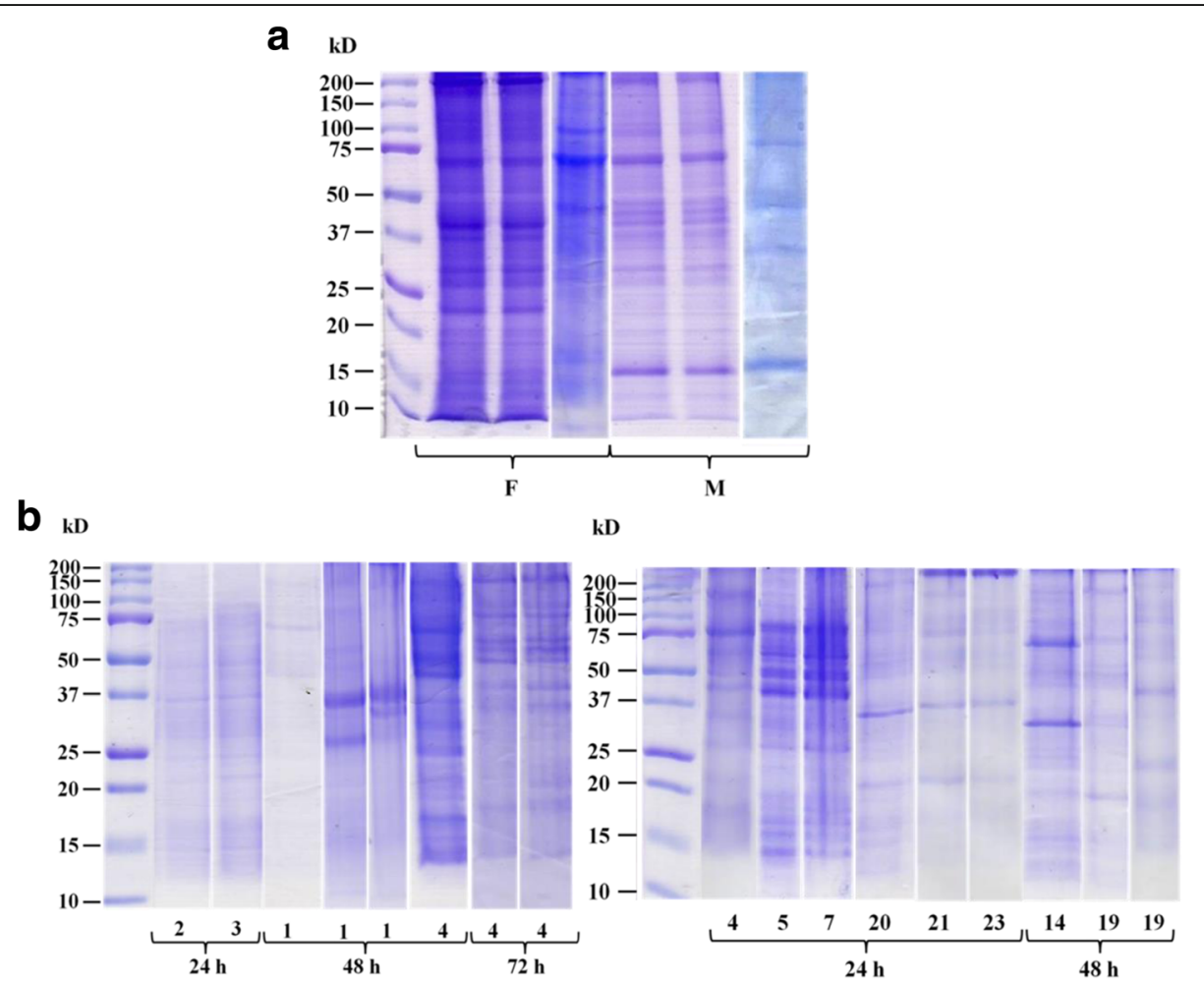

Fig. 1 SDS-PAGE gel analysis of O. ochengi proteins from (a) somatic extracts of male $(\mathrm{m})$ and female $(\mathrm{f})$ worms and $(\mathbf{b})$ of excretory/secretory (ES) products 
females), for which the band separation and intensity are very similar, are shown (Fig. 1b).

Immune recognition of somatic extract and ES proteins from female and male worms of $O$. ochengi and of somatic extract of $\mathrm{O}$. volvulus female filariae by lgG in sera from bovine and human hosts

Antigens (extracts and ES products) from male and female worms of both $O$. volvulus and O. ochengi were recognized in a similar manner by human IgG antibodies from infected patients confirming the closeness between these two species (Figs. 2 and 3).

In total, 28 cattle were included in the longitudinal analysis comparing bovine sera from animals exposed for 4 or 36 months. However, varying numbers of measurements were available at both time points. Figure 3 and Table 1 show the IgG indices for sera from cattle exposed for 4 and 36 months reacting with antigens in extracts of female and male $O$. ochengi. At the 4th month no reactivity was detected in $6(27 \%)$ out of 22 cattle for female and for one (4\%) out of 25 cattle for male antigens. All sera from cattle that had been exposed for 36 months reacted with the proteins in female extracts with an index range between 600 and 1750 .

Looking at the overall distribution of the indices representing the IgG recognition of male as opposed to female ES products and extracted somatic antigens, no significant difference between months 4 and 36 was observed. However, indices of IgG recognition for male $O$. ochengi were at both time points significantly higher than indices for female parasites $(p<0.001)$.

Repeated index measures using female extract as antigen from both time-points were available from 14 cattle, of which 6 (43\%) had an increased and 8 (57\%) a decreased value at month 36 (Fig. 4). Similar results were obtained using extracts from male parasites. From 23 cattle repeated IgG measurements were available, of which 7 (30\%) had an increased and 16 (70\%) had a decreased index in samples taken at month 36.

The IgG indices of reactivity with ES proteins from male and female worms are shown in Fig. 5 and Table 2. Measurements from 25 cattle at month 4 and from 27 cattle at month 36 for both female and male worms of O. ochengi were available. Nineteen (76\%) cattle sera showed no reactivity to female ES proteins at months 4 (non-responders) and five (26\%) of these non-responders reacted after 36 months exposure to transmission by the vector $S$. damnosum. The proportion of detectable IgG indices for ES proteins was comparable at both time points.

Repeated measures for female ES proteins were available for 24 cattle. In the latter, the recognition of the ES proteins remained unchanged (at a value of 0 ) at both time-points in 13 (54\%), increased in 7 (29\%) and

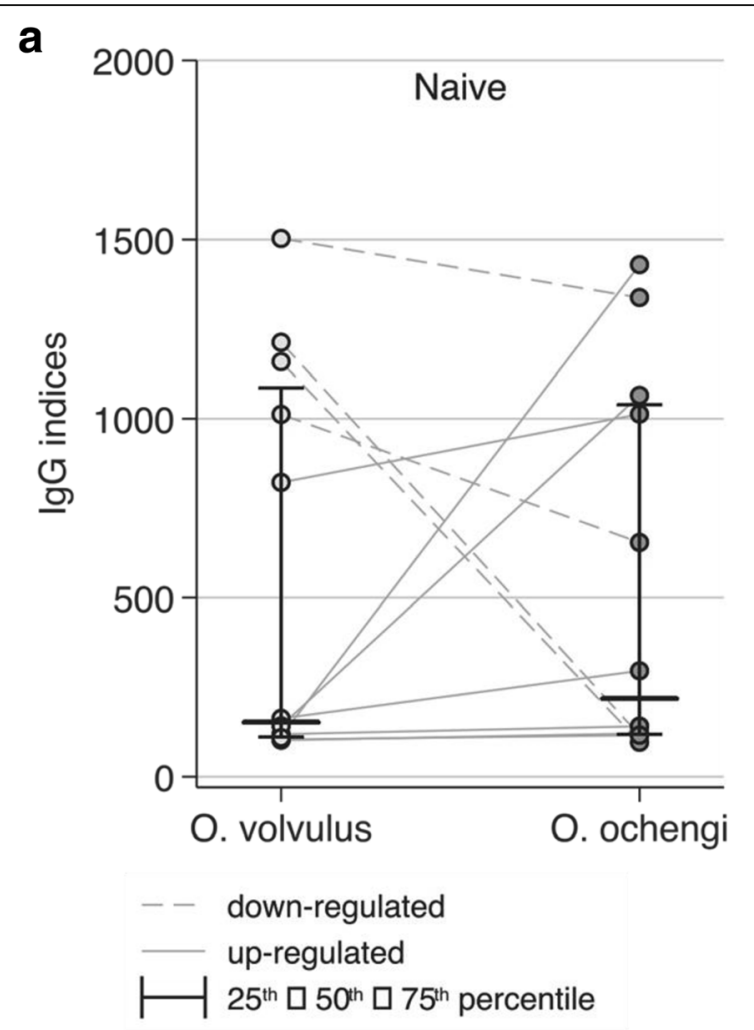

b

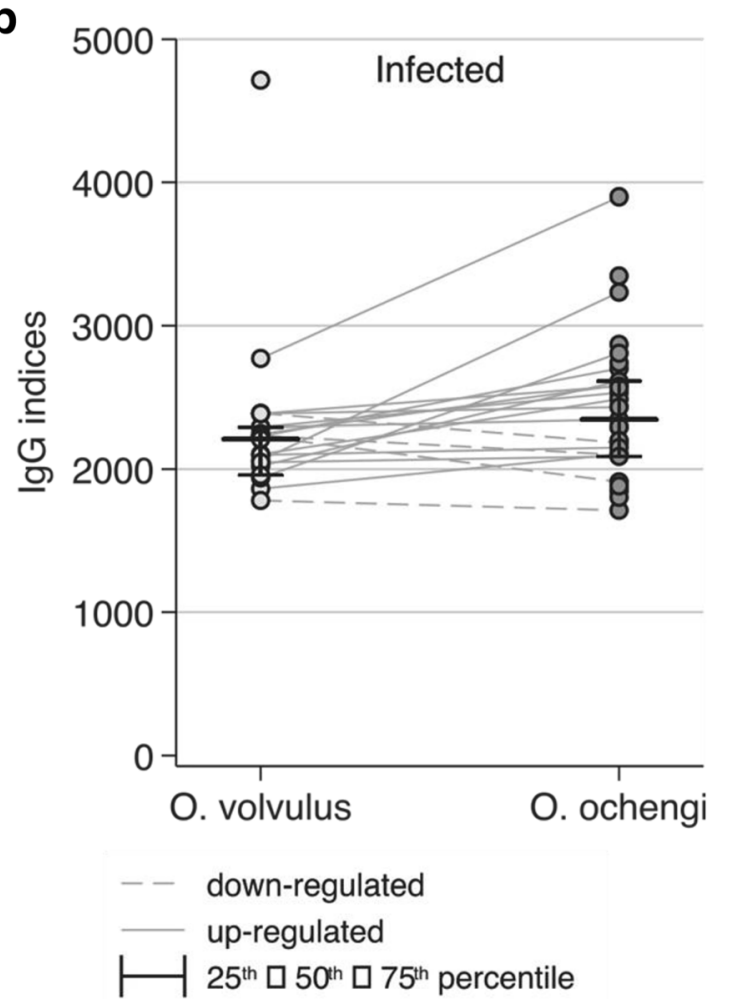

Fig. $2 \mathrm{lgG}$ recognition of proteins in the somatic extracts from $O$. volvulus and $\mathrm{O}$. ochengi female worms using sera from non-exposed persons (a: Naïve) and onchocerciasis patients (b: Infected) 

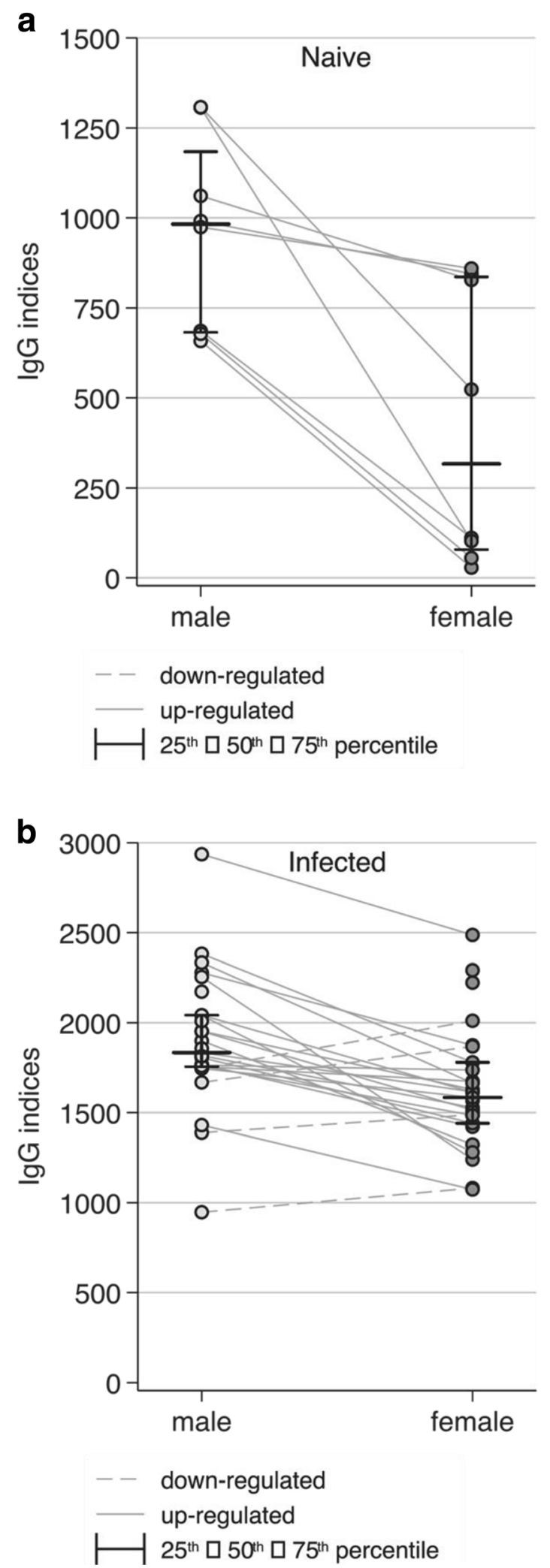

Fig. $3 \mathrm{lgG}$ recognition of proteins in ES products from O. ochengi females and males by sera from non-exposed persons (a: Naive) and onchocerciasis patients (b: Infected) decreased in $4(17 \%)$ cattle. The proportion of samples with increased/decreased IgG indices for ES proteins at month 4 and month 36 was too small for further statistical evaluation. Absence of antibody recognition of ES proteins from male parasites (non-responders) occurred in 13 cattle (52\%) at months 4 and in 12 (44\%) cattle at month 36 indicating no difference between both observation time points. Seven cattle did not react with the male ES proteins (non-responders) at both exposure times. Increased IgG indices were observed in 12 (50\%) while decreased indices occurred in $5(21 \%)$ cattle. The number of repeated increased values for the ES proteins from female parasites was also too low for further evaluation.

Comparing IgG indices at months 4 and 36 indicated that ES proteins from males were more often recognized than female ES antigenic proteins. There was, however, no significant difference for this observation $(p=0.08$ and $p=0.10$, respectively). In the first time point (4 months) sera from 6 cattle (24\%) showed measurable index values for female antigens and $12(48 \%)$ for antigens in male ES while at the second time point (36 months) 9 (33.3\%) sera reacted with female and 15 (55.6\%) with male ES proteins (Table 2).

\section{Discussion}

Proteins released by filarial worms play a significant role in the interaction with their hosts and on the filarial survival as well $[30,31]$. In the present study, O. ochengi ES products collected from female and male worms after various time points revealed diversity in the proteins related to the time of culture and to the number of cultured worms (Fig. 1). At a given time and for a similar number of worms, the displayed band patterns were not absolutely the same, therefore reflecting some possible inner variability of the worms ES products. Elsewhere, a time-dependent protein release was reported for nematodes [32-34]. On notice, the dead or wounded worms with fluid leaking from their body wall were discarded. Any effect of the digestion of the nodule on the vitality and integrity of the females may be excluded since during the first $24 \mathrm{~h}$ of culture, only marginal protein release from females was observed which increased during the following $48 \mathrm{~h}$ (Fig. 1b).

Regarding recognition of ES proteins by cattle sera, it is striking that the indices tended to increase with time in animals which had low indices at 4 months, but fell, when the indices were already high at this young age. There must be an optimum (or undulating) distribution for the indices of individual animals, with a maximum at any time-point before, in between or after 4 to 36 months. More detailed studies on the longitudinal dynamics of the IgG levels over the full course of infection 
Table 1 Comparison of indices of antibody reactivities with antigens in female or male somatic extracts using sera from cattle taken after 4 or 36 months of exposure

\begin{tabular}{ll}
\hline Antigen extract, Exposure time & $\begin{array}{l}\text { Indices of lgG reactivity } \\
\text { Median (IQR) }\end{array}$ \\
\hline Female extract, month 4 & $1068(0-1479)$ \\
Female extract, month 36 & $1154(937-1400)$ \\
Male extract, month 4 & $1739(1526-1861)$ \\
Male extract, month 36 & $1641(1490-1933)$ \\
& Wilcoxon signed-rank test \\
$\begin{array}{l}\text { Female extract, month } 4 \text { vs. Female } \\
\text { extract, month } 36\end{array}$ & $p=0.98$ \\
$\begin{array}{l}\text { Male extract, month } 4 \text { vs. Male extract, } \\
\text { month 36 }\end{array}$ & $p=0.35$ \\
$\begin{array}{l}\text { Female extract, month } 4 \text { vs. Male } \\
\text { extract, month } 4\end{array}$ & $p<0.001$ \\
Female extract, month 36 vs. Male & $p<0.001$ \\
extract, month 36 & \\
\hline OR interqurtl range &
\end{tabular}

IQR interquartile range

(more than 6 years) and at higher frequencies (bi- or three-monthly intervals) are still under course.

For O. volvulus, partially similar protein bands had been observed by Sakwe et al. [33] as at $10-20 \mathrm{kDa}$, about $40 \mathrm{kDa}$ and $60 \mathrm{kDa}$. Cho-Ngwa et al. [35] analyzing nodular fluid proteins, so-called in vivo ES products of $O$. ochengi, observed partially similar protein bands. Thus, like Cho-Ngwa et al. (2011), in the present study

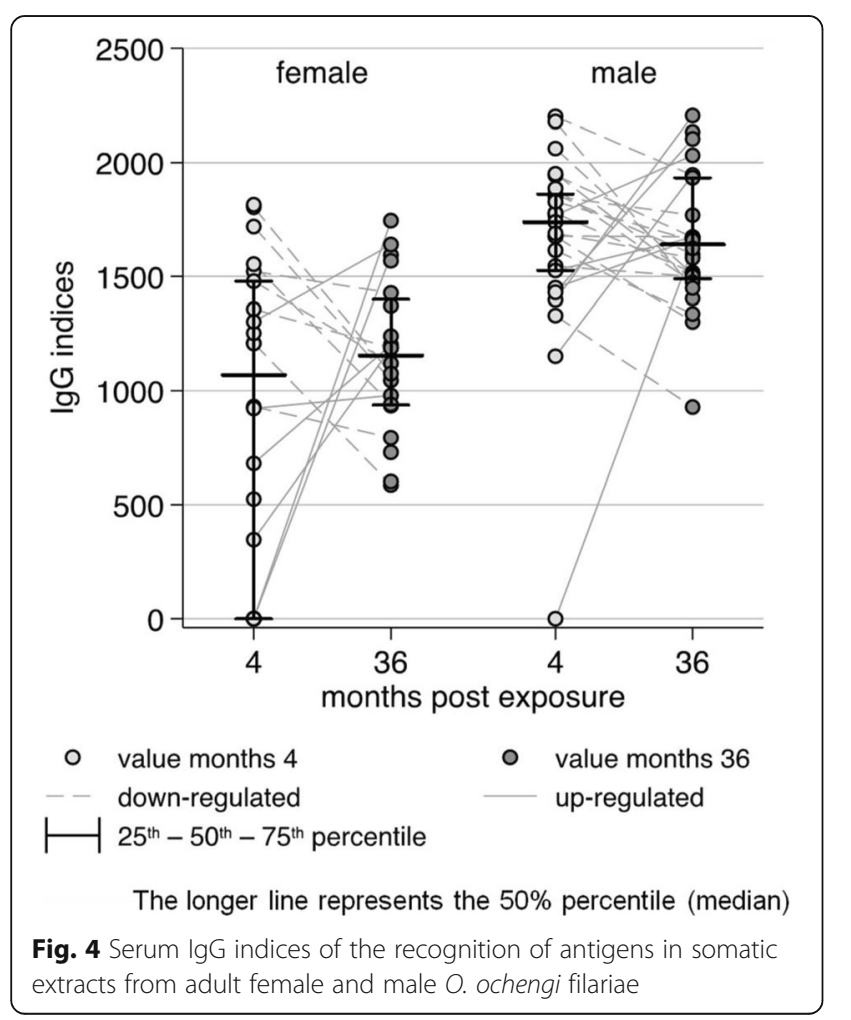

we also found prominent protein bands between 40 and 70 and $90 \mathrm{kDa}$, in particular for ES from male filariae (Fig. 1b) which may comprise the dominant protein OV1CF of $62.4 \mathrm{kDa}$ reported by Cho-Ngwa et al. [35]. This indicates that these proteins may be released from living males or females in the nodule. In addition, the $41 \mathrm{kDa}$ enolase and $38 \mathrm{kDa}$ glyceraldehyde-3-phosphatedehydrogenase listed by Cho-Ngwa et al. may be present in these ES proteins which were studied by our group $[36,37]$. Three generated potential diagnostic monoclonal antibodies also reacted with proteins of $20-220 \mathrm{kDa}$ which were also recognized by sera from Onchocerca-infected cattle as well as humans [21]. The similar reactivity of the sera from $O$. ochengi-infected cattle to that of $O$. volvulus-infected humans with both, O. volvulus and $O$. ochengi proteins reflects the reported physiological closeness [13] and phylogenetic relationship between the two parasites [16, 38].

The present study is limited to a description of a demonstration of multiple differing proteins in male and female ES products. More detailed analysis can be addressed by mass spectrometry analyses [14].

No correlation between the indices for the IgG recognition of antigens in the extracts and ES proteins measured at months 4 were observed. However, positive ES indices measured at months 36 were mainly detected in cattle with increased indices for recognition of extract antigens.

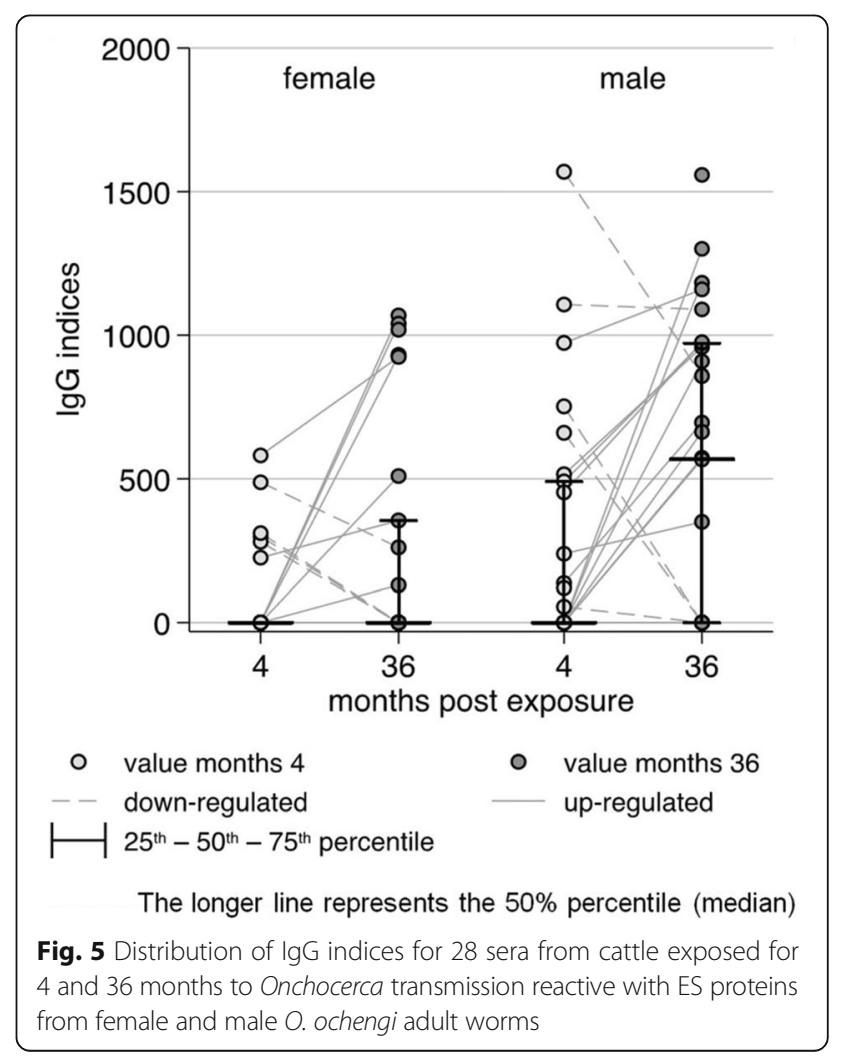


Table 2 Comparison of indices of cattle antibody reactivities with female or male excretory/secretory (ES) products after 4 or 36 months of exposure

\begin{tabular}{ll}
$\begin{array}{l}\text { Worm sex, Exposure time } \\
\text { (number of worms) }\end{array}$ & $\begin{array}{l}\text { Indices of IgG reactivity for ES proteins } \\
\text { (if }>0)\end{array}$ \\
& Median (IQR) \\
female, months 4 (6) & $305(280-488)$ \\
female, months 36 (9) & $924(355-1019)$ \\
male, months 4 (12) & $504(188-863)$ \\
male, months 36 (15) & $958(664-1160)$ \\
& Indices for ES proteins =0 vs. ES proteins >0 \\
& Chi square test \\
female 4 vs. female 36: & $6 / 25(24 \%)$ vs. 9/27 (33\%); $p=0.46$ \\
male 4 vs. male 36: & $12 / 25(48 \%)$ vs. 15/27 (56\%); $p=0.59$ \\
female 4 vs. male 4: & $6 / 25(24 \%)$ vs. 12/25 (48\%); $p=0.08$ \\
female 36 vs. male 36: & $9 / 27(33 \%)$ vs. 15/27 (56\%); $p=0.10$ \\
\hline
\end{tabular}

$I Q R$ interquartile range

The present results depict the diverse pattern of immune reactivity of cattle sera with proteins arising from male and female worms. The higher antibody response to male ES proteins can be related to their migratory behaviour in the host as compared to the sessile females in the nodules leading to increased immune interference. This result has not yet been published from any other filaria or helminth. Of note, cattle IgG1 is reported to be transferred maternally through colostrum [25], which can be detected in the investigated sera and which can operate in the calves during the first months and possibly may induce the reduced establishment of $O$. ochengi in the calves.

The decreased reactivity observed in many infected cattle could refer to the modulation of the immune system by the parasite which may be mediated by released products. An important impact on the immunological reactivities may result from the frequent co-infection by filarial species or other nematodes in our cattle e.g. by O. gutturosa, O. armillata and Setaria etc. [39]. In addition, some contributions may be attributed to compounds of the endosymbiotic Wolbachia endobacteria, present in female as compared to male filariae [24, 26, 40-42].

Parasitic helminths secrete products which have been increasingly reported to dampen their host immune response against them. These products referred to as immunomodulatory components of helminths facilitate the establishment and propagation of the parasite [9-11, 30, 43]. Further investigations namely mass spectrometry and bioinformatics analyses on these Onchocerca ES products are currently being performed [14, 16]. In order to elaborate an efficient vaccine against onchocerciasis, identifying the proteins in $O$. ochengi ES products and analysing their structure and functions in host-parasite interactions should definitely be the main focus.

\section{Conclusions}

The performed ELISA analyses demonstrated the antigenicity of Onchocerca spp. proteins. Furthermore, the observed cross-reactivity is an extra proof of the phylogenetic closeness of $O$. volvulus and $O$. ochengi. More specifically, this study firstly revealed a stronger recognition of male filariae proteins by host antibodies. The detection, isolation and hybridization of each involved $O$. ochengi ES protein will create the possibility to evaluate their potentials as vaccine candidates.

\section{Abbreviations \\ BSA: Bovine serum albumin; ELISA: Enzyme linked immuo-sorbent assay; ES: Excretory and secretory; IQR: Interquartile range; PBS: Phosphate buffered saline; SDS PAGE: Sodium dodecyl sulphate polyacrylamide gel electrophoresis; TCA: Trichloroacetic acid; TMB: Tetramethylbenzidine}

\section{Acknowledgments}

This work is a part of the PhD thesis of B.D. We thank Dipl. biol. Sarah Reiling for her contribution to the production of the parasite material and, in addition, Jeremie Yembo, David Ekale and George Tamenai from the "Programme Onchocercoses" technical staff for technical help. We also acknowledge Professor Charles E. Bell of the Ohio State University (USA) and Dr. Willie Mushing of the Department of English at the University of Ngaoundéré for language revision of the manuscript. Finally, we thank Prof. Christina Strube, University of Veterinary Medicine (Hanover, Germany) for supplying sera from naïve cattle non-exposed to O. ochengi-infected S. damnosum.

\section{Funding}

This research was supported by funds provided by the Deutsche Forschungsgemeinschaft (DFG) to the Cameroonian-German Cooperation Project (CGCP), (grant LI 793/5-1). The work in the PO-laboratory (www.riverblindness.eu) and at IRAD was financed through DFG grant RE 1536/2-1.

\section{Availability of data and materials}

The datasets used and/or analysed during the current study are available from the corresponding author on reasonable request.

\section{Authors' contributions}

Conception and design: DB, DN, AR, MDA, EL, NB. Acquisition of data: DB, $D N, A E, K M, A P, N N N$, JDV, BA, RK, SVH, AR, MDA, EL, NB. Analysis and interpretation of data: DB, DN, AE, KM, AP, NNN, JDV, BA, RK, SVH, AR, MDA, $E L, N B$. Drafting the manuscript: $D B, D N, A E, K M, A R, M D A, E L, N B$. Revising the manuscript critically for important intellectual content: DB, DN, AR, MDA, EL, NB. Giving final approval of the version to be published: DN, AR, MDA, EL, NB. Also MDA and AR set up and ran experiments that provided sera that were used for this study. All the authors read and approved the final manuscript.

\section{Ethics approval and consent to participate}

We hereby declare that skin samples of cattle containing palpable nodules were collected at the slaughterhouse of Ngaoundéré with the permission of animal Health Authorities of the Adamawa Region in Ngaoundéré, Cameroon. The collection of blood samples from humans and cattle for research purposes was approved by the Ethics Commission of the Medical Board in Hamburg (Germany) and by the ethical committees and health authorities in the respective countries, in accordance with the principles of the Helsinki declaration of 1975, revised 2000.

\section{Competing interests}

The authors declare that they have no competing interests.

\section{Publisher's Note}

Springer Nature remains neutral with regard to jurisdictional claims in published maps and institutional affiliations. 


\section{Author details}

'University of Ngaoundéré, Faculty of Science, Ngaoundéré, Cameroon. ${ }^{2}$ Programme Onchocercoses, Field research station of the University of Tübingen, Ngaoundéré, Cameroon. ${ }^{3}$ Eberhard Karls University, Institute of Evolution and Ecology, Comparative Zoology, Tübingen, Germany. ${ }^{4}$ Veterinary Research Laboratory, IRAD Wakwa Regional Centre, Ngaoundéré, Cameroon. ${ }^{5}$ Bernhard Nocht Institute of Tropical Medicine, Disease Epidemiology Department, Hamburg, Germany. ${ }^{6}$ University of Münster, Münster, Germany. ${ }^{7}$ TOZARD Research Laboratory, P.O. box 59, Bambili-Tubah, Bamenda, Cameroon.

\section{Received: 22 August 2017 Accepted: 24 April 2018} Published online: 02 May 2018

\section{References}

1. GBD 2016 Disease and Injury Incidence and Prevalence Collaborators. Global, regional, and national incidence, prevalence, and years lived with disability for 328 diseases and injuries for 195 countries, 1990-2016: a systematic analysis for the global burden of disease study 2016. Lancet Lond Engl. 2017;390:1211-59. Available from: https://www.ncbi.nlm.nih.gov/ pmc/articles/PMC5605509/.

2. Schulz-Key H, Karam M. Periodic reproduction of Onchocerca volvulus. Parasitol Today. 1986;2:284-6. Available from: http://www.sciencedirect.com/ science/article/pii/0169475886901389.

3. Plaisier AP, van Oortmarssen GJ, Remme J, Habbema JD. The reproductive lifespan of Onchocerca volvulus in West African savanna. Acta Trop. 1991;48: 271-84. Available from: Available from: https://www.sciencedirect.com/ science/article/pii/0001706X9190015C?via\%3Dihub.

4. Wahl G, Achu-Kwi MD, Mbah D, Dawa O, Renz A. Bovine onchocercosis in North Cameroon. Vet Parasitol. 1994;52:297-311. Available from: https:// www.ncbi.n/m.nihgov/pubmed/8073613.

5. Renz A, Trees AJ, Achu-Kwi D, Edwards G, Wahl G. Evaluation of suramin, ivermectin and CGP 20376 in a new macrofilaricidal drug screen, Onchocerca ochengi in African cattle. Trop Med Parasitol. 1995;46:31-7. Available from: https://www.ncbi.nlm.nih.gov/pubmed /7631125.

6. Trees AJ, Wood VL, Bronsvoort M, Renz A, Tanya VN. Animal models Onchocerca ochengi and the development of chemotherapeutic and chemoprophylactic agents for onchocerciasis. Ann Trop Med Parasitol. 1998; 92(Suppl 1):S175-9. Available from: https://www.ncbi.nlm.nih.gov/pubmed/ 9861291.

7. Achukwi M, Harnett W, Bradley J, Renz A. Onchocerca ochengi acquisition in zebu Gudali cattle exposed to natural transmission: parasite population dynamics and IgG antibody subclass responses to Ov10/Ov11 recombinant antigens. Vet Parasitol. 2004;122:35-49. Available from: https://www. sciencedirect.com/science/article/pii/S0304401704000792?via\%3Dihub.

8. Makepeace BL, Tanya VN. 25 years of the Onchocerca ochengi model. Trends Parasitol. 2016;32:966-78. Available from: http://www.cell.com/trends/ parasitology/abstract/S1471-4922(16)30143-X.

9. Hewitson JP, Grainger JR, Maizels RM. Helminth immunoregulation: the role of parasite secreted proteins in modulating host immunity. Mol Biochem Parasitol. 2009;167:1-11. Available from: https://www.sciencedirect.com/ science/article/pii/S0166685109001224.

10. Shepherd C, Navarro S, Wangchuk P, Wilson D, Daly NL, Loukas A. Identifying the immunomodulatory components of helminths. Parasite Immunol. 2015;37:293-303. Available from: http://onlinelibrary.wiley.com/ doi/10.1111/pim.12192/abstract.

11. Ditgen D, Anandarajah EM, Hansmann J, Winter D, Schramm G, Erttmann $K D$, et al. Multifunctional thioredoxin-like protein from the gastrointestinal parasitic nematodes Strongyloides ratti and Trichuris suis affects mucosal homeostasis. J Parasitol Res. 2016; Available from: http://www.ncbi.nlm.nih. gov/pmc/articles/PMC5107843/.

12. McSorley HJ, Hewitson JP, Maizels RM. Immunomodulation by helminth parasites: defining mechanisms and mediators. Int J Parasitol. 2013;43:30110. Available from: https://www.sciencedirect.com/science/article/pii/ S0020751912003165?via\%3Dihub.

13. Hoch B, Wahl G, Enyong P, Lüder C, Harnett W, Schulz-Key H, et al. Onchozerkose in Mensch und Rind: Serologische Erkennung von artspezifischen und kreuzreaktiven Antigenen. ÖGTPM. http://docplayer.org/ 64655931-Onchozerkose-in-mensch-und-rind-serologische-erkennung-vonartspezifischen-und-kreuzreaktiven-antigenen.html.
14. Eberle R, Brattig NW, Trusch M, Schlüter H, Achukwi MD, Eisenbarth A, et al. Isolation, identification and functional profile of excretory-secretory peptides from Onchocerca ochengi. Acta Trop. 2015;142:156-66. Available from: https://www.sciencedirect.com/science/article/pii/S0001706X14003842.

15. Achukwi MD, Harnett W, Enyong P, Renz A. Successful vaccination against Onchocerca ochengi infestation in cattle using live Onchocerca volvulus infective larvae. Parasite Immunol. 2007;29:113-6. Available from: http:// onlinelibrary.wiley.com/doi/10.1111/j.1365-3024.2006.00917.x/abstract.

16. Armstrong SD, Xia D, Bah GS, Krishna R, Ngangyung HF, LaCourse EJ, et al. Stage-specific proteomes from Onchocerca ochengi, sister species of the human river blindness parasite, uncover adaptations to a nodular lifestyle. Mol Cell Proteomics. 2016;15:2554-75. Available from: https://www.ncbi.nlm. nih.gov/pmc/articles/PMC4974336/.

17. Lustigman S, Makepeace BL, Klei TR, Babayan SA, Hotez P, Abraham D, et al. Onchocerca volvulus: the road from basic biology to a vaccine. Trends Parasitol. 2018;34:64-79. Available from: http://www.cell.com/trends/ parasitology/abstract/S1471-4922(17)30229-5.

18. Cho-Ngwa F, Akoachere M, Titanji VPK. Sensitive and specific serodiagnosis of river blindness using Onchocerca ochengi antigens. Acta Trop. 2003;89: 25-32. Available from: http://linkinghub.elsevier.com/retrieve/pii/ S0001706X03002249.

19. Piedrafita D, Raadsma HW, Prowse R, Spithill TW. Immunology of the hostparasite relationship in fasciolosis (Fasciola hepatica and Fasciola gigantica). Can J Zool. 2004;82:233-50. Available from: http://www.nrcresearchpress. com/doi/abs/10.1139/z03-216.

20. Albiez EJ, Büttner DW, Schulz-Key H. Studies on nodules and adult Onchocerca volvulus during a nodulectomy trial in hyperendemic villages in Liberia and upper Volta. II. Comparison of the macrofilaria population in adult nodule carriers. Tropenmed Parasitol. 1984;35:163-6. Available from: https://www.ncbi.n/m.nih.gov/pubmed/6541822.

21. Cho-Ngwa F, Daggfeldt A, Titanji VP, Grönvik K-O. Preparation and characterization of specific monoclonal antibodies for the detection of adult worm infections in onchocerciasis. Hybridoma. 2005;24:283-90. Available from: http://online.liebertpub.com/doi/abs/10.1089/hyb.2005.24.283.

22. Ndjonka D, Agyare C, Lüersen K, Djafsia B, Achukwi D, Nukenine EN, et al. In vitro activity of Cameroonian and Ghanaian medicinal plants on parasitic (Onchocerca ochengi) and free-living (Caenorhabditis elegans) nematodes. J Helminthol. 2010;85:304-12. Available from: http://www.journals.cambridge. org/abstract_S0022149X10000635.

23. Brattig NW, Krawietz I, Abakar AZ, Erttmann KD, Kruppa TF, Massougbodji A. Strong lgG isotypic antibody response in sowdah type onchocerciasis. J Infect Dis. 1994;170:955-61. Available from: https://www.ncbi.nlm.nih.gov/ pubmed/7930741.

24. Brattig NW. Pathogenesis and host responses in human onchocerciasis: impact of Onchocerca filariae and Wolbachia endobacteria. Microbes Infect. 2004;6:113-28. Available from: http://linkinghub.elsevier.com/retrieve/pii/ S1286457903003101.

25. Manchang TK, Ajonina-Ekoti I, Ndjonka D, Eisenbarth A, Achukwi MD, Renz A, et al. Immune recognition of Onchocerca volvulus proteins in the human host and animal models of onchocerciasis. J Helminthol. 2015;89:375-86. Available from: http://www.journals.cambridge.org/abstract_ S0022149X14000224.

26. Brattig NW, Bazzocchi C, Kirschning CJ, Reiling N, Buttner DW, Ceciliani F, et al. The major surface protein of Wolbachia endosymbionts in filarial nematodes elicits immune responses through TLR2 and TLR4. J Immunol. 2004;173:437-45. Available from: http://www.jimmunol.org/cgi/doi/10.4049/ jimmunol.173.1.437.

27. Mpagi JL, Büttner DW, Tischendorf FW, Erttmann KD, Brattig NW. Humoral responses to a secretory Onchocerca volvulus protein: differences in the pattern of antibody isotypes to recombinant Ov20/ OvS1 in generalized and hyperreactive onchocerciasis. Parasite Immunol. 2000;22:455-60. Available from: https://onlinelibrary.wiley.com/doi/abs/ 10.1046/j.1365-3024.2000.00325.x.

28. Kemeny DM. Titration of antibodies. J Immunol Methods. 1992;150:57-76. Available from: http://www.sciencedirect.com/science/article/pii/ 0022175992900652.

29. Miura K, Orcutt AC, Muratova OV, Miller LH, Saul A, Long CA. Development and characterization of a standardized ELISA including a reference serum on each plate to detect antibodies induced by experimental malaria vaccines. Vaccine. 2008;26:193-200. Available from: http://www. sciencedirect.com/science/article/pii/0022175992900652. 
30. Harnett W. Secretory products of helminth parasites as immunomodulators. Mol Biochem Parasitol. 2014;195:130-6. Available from: https://www. sciencedirect.com/science/article/pii/S0166685114000383?via\%3Dihub.

31. Ditgen D, Anandarajah EM, Meissner KA, Brattig N, Wrenger C, Liebau E. Harnessing the helminth secretome for therapeutic immunomodulators. Biomed Res Int. 2014;2014:964350. Available from: https://www.ncbi.nlm.nih. gov/pmc/articles/PMC4123613/.

32. Drake $L$, Bianco AE, Bundy DA, Ashall F. Characterization of peptidases of adult Trichuris muris. Parasitology. 1994;109(Pt 5):623-30. Available from: https://www.ncbi.nlm.nih.gov/pubmed/7831097.

33. Sakwe AM, Evehe MS, Titanji VP. In vitro production and characterization of excretory/secretory products of Onchocerca volvulus. Parasite Paris Fr. 1997;4: 351-8. Available from: https://www.parasite-journal.org/articles/parasite/abs/ 1997/04/parasite1997044p351/parasite1997044p351.html.

34. Gadahi JA, Wang S, Bo G, Ehsan M, Yan R, Song X, et al. Proteomic analysis of the excretory and secretory proteins of Haemonchus contortus (HCESP) binding to goat PBMCs in vivo revealed stage-specific binding profiles. PLoS One. 2016;11 Available from: https://www.ncbi.nlm.nih.gov/pmc/articles/ PMC4965049/.

35. Cho-Ngwa F, Zhu X, Metuge JA, Daggfeldt A, Grönvik K-O, Orlando R, et al. Identification of in vivo released products of Onchocerca with diagnostic potential, and characterization of a dominant member, the OV1CF intermediate filament. Infect Genet Evol. 2011;11:778-83. Available from: http://linkinghub.elsevier.com/retrieve/pii/S1567134810002169.

36. Steisslinger V, Korten S, Brattig NW, Erttmann KD. DNA vaccine encoding the moonlighting protein Onchocerca volvulus glyceraldehyde-3-phosphate dehydrogenase (Ov-GAPDH) leads to partial protection in a mouse model of human filariasis. Vaccine. 2015;33:5861-7. Available from: https://www. sciencedirect.com/science/article/pii/S0264410X15011603?via\%3Dihub.

37. Jolodar A, Fischer P, Bergmann S, Büttner DW, Hammerschmidt S, Brattig NW. Molecular cloning of an alpha-enolase from the human filarial parasite Onchocerca volvulus that binds human plasminogen. Biochim Biophys Acta. 2003;1627:111-20. Available from: https://www.sciencedirect.com/science/ article/pii/S0167478103000836?via\%3Dihub.

38. Morales-Hojas R, Cheke RA, Post RJ. A preliminary analysis of the population genetics and molecular phylogenetics of Onchocerca volvulus (Nematoda: Filarioidea) using nuclear ribosomal second internal transcribed spacer sequences. Mem Inst Oswaldo Cruz. 2007;102:879-82. Available from: http:// www.scielo.br/scielo.php?script=sci_arttext\&pid=S0074-02762007000700016.

39. Renz A. Onchocerciasis, bovine. In: Encycl arthropod-Transm infect man Domest Anim. Wallingford: CABl; 2001. p. 375-81.

40. Kozek WJ, Marroquin HF. Intracytoplasmic bacteria in Onchocerca volvulus. Am J Trop Med Hyg. 1977;26:663-78. Available from: http://www.ajtmh.org/ content/journals/10.4269/ajtmh.1977.26.663.

41. Saint André A v, Blackwell NM, Hall LR, Hoerauf A, Brattig NW, Volkmann L, et al. The role of endosymbiotic Wolbachia bacteria in the pathogenesis of river blindness. Science. 2002;295:1892-5. Available from: https://www.ncbi. nlm.nih.gov/pubmed/11884755

42. Hise AG, Gillette-Ferguson I, Pearlman E. The role of endosymbiotic Wolbachia bacteria in filarial disease. Cell Microbiol. 2003;6:97-104. Available from: https:/ onlinelibrary.wiley.com/doi/abs/10.1046/j.1462-5822.2003.00350.x.

43. Hartmann W, Brenz Y, Kingsley MT, Ajonina-Ekoti I, Brattig NW, Liebau E, et al. Nematode-derived proteins suppress proliferation and cytokine production of antigen-specific T cells via induction of cell death. PLoS One. 2013;8 Available from: https://www.ncbi.nlm.nih.gov/pmc/articles/ PMC3693813/

\section{Ready to submit your research? Choose BMC and benefit from:}

- fast, convenient online submission

- thorough peer review by experienced researchers in your field

- rapid publication on acceptance

- support for research data, including large and complex data types

- gold Open Access which fosters wider collaboration and increased citations

- maximum visibility for your research: over $100 \mathrm{M}$ website views per year

At BMC, research is always in progress.

Learn more biomedcentral.com/submissions 